\title{
The Effects of Sudden Stops on the Turkish Economy: A Structural VAR Approach ${ }^{1}$
}

\author{
Bilge Kagan Ozdemir ${ }^{\mathrm{a}}$, Mehmet Obekcan ${ }^{\mathrm{b}}$
}

Abstract: This study investigates the effects of the sudden stop problem on the economic performance of emerging market economies in Turkey sampling. In this context, this study is driven by small-open economy assumption and Fed effective funds rate used as an external triggering factor that causes sudden stop by taking into account the related literature. To evaluate the effects of sudden stop problem on domestic economy, interest rate, credits to private sector, current account balance, current financial account, real effective exchange rate, consumer price index and industrial production index are selected as domestic variables which supposed related to the resilience of sudden stops. Data, which used in the study, are monthly and they span from 2003:01 to 2019:09. In addition, the SVAR model with block exogeneity is applied as empirical method. The results of the study show that an unexpected increase in Fed effective interest rate trigger to decreases in capital inflow. As capital inflow decreases, real effective exchange rate, credits to private sector and industrial production decreases, also interest rate and consumer price index and current account balance increase. These results suggest that external factors are effective in triggering sudden stop problem.
Keywords: Capital Inflows, Sudden Stop, External Shocks, SVAR, Block Exogeneity

JEL: E44 F32 F34

\section{Introduction}

Since beginning of 1990s, emerging market economies have been heavily exposed to capital inflows. Emerging Market Economies (EMEs) including Turkey have benefited from these capital inflows in a variety of areas, such as funding of investment, ensuring sustainable growth and protection of price stability. This case has made EMEs more dependent on capital inflows in the terms of several aspects. However, capital outflows from EMEs due to various reasons has caused serious problems for EMEs. For example, Mexico has experienced very large capital inflows in this process. In the last quarter of 1994 these capital inflows slowed down and unexpected outflows started. The capital outflows during this period had negatively affected exchange rate system and financial structure of Mexico as a consequence of that peso depreciated by about $50 \%$.

The developments in Mexico have affected emerging economies in negative way but this situation didn't last long. Since, EMEs have higher interest rate than developed ones and they have shown good economic performance, capital inflows into developing country economies have accelerated. The crisis that started in Thailand in 1997 affected an entire Asian area and Indonesia and South Korea, has come to the

a Assoc. Prof., PhD., Anadolu University, Faculty of Economics and Administrative Sciences, Department of Economics, Eskişehir, Turkiye, bilgeko@anadolu.edu.tr (ORCID ID: 0000-0002-8716-9305)

b Res. Asst., Hitit University, Faculty of Economics and Administrative Sciences, Department of Economics, Corum, Turkiye, mehmetobekcan@hitit.edu.tr (ORCID ID: 0000-0001-5713-2811) 
brink of bankruptcy. Although, South Korea is better than Indonesia and Thailand in terms of economic indicators such as low current account deficit, it has lived through same destiny. In this period, Malaysia was affected by these troubles in the region. However, the controls that applied on capital inflows and outflows by Malaysia mitigated the effects of the crisis and it was less affected by this process than other countries. The crisis that occurred in Russia in 1998 is the last ring of this chain in the terms of EMEs.

When it is evaluated in terms of Turkey which is one of emerging market economies, capital inflows have started in 1989 with legal regulations. Capital inflows have increased exponentially since this date. The structural problems that arise in Turkey during this process of financialization and external shocks caused sudden stops in capital inflows.

Although the crises of 1994, 2000 and 2001 have different characteristics, problems of capital inflows lie at the heart of all. After EMEs crises, capital flows in EMEs has become a controversial subject. This case has prompted economists and policy makers to study the causes and consequences of international capital movements. Especially, sudden stops in capital inflows are the center of these studies. From this viewpoint, in this study, the effects of a sudden stop problem on Turkey's economic performance has been investigated. After the 2001 crisis, Turkish economy has passed a new monetary program with the implementation of disciplined fiscal policies, adaptation of inflation targeting regimes and floating exchange rate regime as of 2002 and structural reforms to decrease fragilities against external shocks. The high growth rates, appreciation in Turkish Lira (TL) and price stability performed by means of the reforms that implemented by policy makers in Turkey attract massive capital flows. However, appreciation in Turkish Lira causes to substitute domestic inputs with export products as well. This situation causes high current account deficit despite highly export performance. Increasing current account deficit has brought the sustainability of current account deficit to the agenda. With the 2008 global financial crisis, the fluctuations in the world economy have become problematic for Turkey due to current account deficit financed by short-term capital flows. This process makes Turkish economy vulnerable to external shocks and sudden stop. Especially, the slowdown in short-term capital flows and the capital flows which are mostly portfolio investments have made these external vulnerabilities more prominent in Turkey.

In this study, the effects of sudden stop in capital flows on Turkish economic performance at period between 2003:01 and 2019:09 with monthly data is investigated. Moreover, the study is driven by smallopen economy assumption and our variables are chosen in a similar way to previous studies in the literature. The SVAR model with block exogeneity, used in Sims (1986) and Zha, (1999), is employed as empirical method that provides simultaneous interaction between internal and external variables in the model. By means of this method, while the external factor is Fed funds rate which is proxy for world interest rate has effects on domestic variables, domestic variables have not effects on it and also domestic variables have interaction among each other. Therefore, small-open economy assumption is satisfied.

\section{Theoretical Background of the Study}

Sudden stop concept is firstly developed by Dornbusch, Goldfajn and Valdes (1995), is kind of aphorism used by bankers and quoted by bankers as "it is not that speed kills, it is Sudden Stop". However, in terms of empirical side, the first study associated with sudden stop was conducted by Calvo (1998).

Sudden, large and unexpected negative fluctuations in capital inflows are defined as the main characteristics of the Sudden Stop phenomenon (Mendoza, 2001; Reinhart \& Calvo, 2001; Edwards, 2004). In his study to investigate crises in emerging market economies, Mendoza (2002) stated that sudden stop phenomenon has an important role in triggering crises. This study stated that changes in economic fundamentals such as sudden access to the international capital market, major deteriorations in the current account deficit, decreases in production and aggregate demand, corrections in asset prices and exchange rate depreciation caused Sudden Stop. Caballero and Krishnamurthy (2001) described the weakness in the domestic financial markets and the improper behavior of representatives of domestic agents as the main cause of Sudden Stops in EMEs. Calvo, Izquierdo ve Mejía (2004) have extended the concept of Sudden Stop by adding new criteria including synchronous output contraction. Calvo et al. (2008) has added a new concept 
known as '3S' which means systematic sudden stops. This new concept takes account of external financial factors rather than domestic concepts. The main starting point of this approach is the need to increase the internal interest rate in the event of a sudden stop due to external financial shocks. In other words, domestic interest rate will increase sharply due to the catching of the global component.

Sturzenegger et al. (2003) examined which factors lead to different output performance after a sudden stop. They found that the floating exchange rate and higher degree of openness had a positive effect on output performance, but higher current account deficit and debt dollarization had a negative effect on output performance. Hutchison and Noy (2006), on the other hand, described that the sudden stop caused a sharp decline in domestic investment, production and employment due to the realignment process in the real exchange.

In order to differentiate the concept of Sudden Stop from capital outflows, some quantitative studies have been conducted in the literature. According to Edward (2004), the decrease in net capital inflows exceeding $5 \%$ of GDP in a year is considered as Sudden Stop. According to Guidotti et al. (2004), the changes in which the annual change in the capital account is below one standard deviation from the average of the capital account and at the same time are more than 5\% of GDP are considered as Sudden Stop. In another quantitative definition, Hutchison and Noy (2006) considered that the current account decreased by at least $3 \%$ of GDP as Sudden Stop.

Calvo, Izquierdo and Talvi (2006) took quantitative definitions one step further. According to them, a sudden stop can be defined as a major decrease in capital flows exceeding the average change in the current account/GDP ratio by more than two standard deviations above this average rate on an annual basis. In addition, Rothenberg and Warnock (2011) and Calvo et al. (2008) can be considered as other examples among the studies in the literature on the quantification of the subject.

Another controversial view in the literature on the effects of Sudden Stop concerns the role of trade openness against external shocks. Openness, defined as high international trade/GDP ratio, plays an important role in the recovery after the sudden stop or cushion against the sudden stop. According to Guidotti et al. (2004) and Cavallo and Frankel (2008) openness provides safeguard system to country because more openness causes a country to become less risk for default and to quickly recover against output contraction.

According to Stiglitz (2002), openness may be a problem for the sustainability of public deficits for developing countries, therefore restrictive policies for the degree of capital mobility may reduce the likelihood of external crises such as sudden stop. In the study of Winters (2002), it was concluded that when developing countries encounter external financial shocks, their effects vary depending on the degree of foreign trade liberalization. Loayza and Raddatz (2007) suggest that trade deficit is the most important feature that contributes to adverse effects on the production levels of developing countries.

On the other hand, Frankel and Rose (2002) provided an empirical study of the role of openness in vulnerability to external financial shocks to EMEs. According to the results of his study, if a country's trade/GDP ratio is high, investors are less likely to escape from that country because the risk of default is relatively low. After this study, Guidotti et al. (2004) expressed similar results and concluded that economies with more openness recovered faster after output contraction caused by Sudden Stops. In another empirical study, Cavallo and Frankel (2008) state that an economy with greater trade openness would be less vulnerable to both external shocks and monetary collapses.

The studies testing the effects of the sudden stop problem on the economic performance for the Turkish economy are rather limited. Wu et al. (2019), investigated the factors that determine the financial volatility of emerging market, included Turkey, in relation to external shocks for the period between 1990 and 2018. As a result of panel regression model covering 30 emerging markets the study showed that countries such as Argentina, South Africa and Turkey affected negatively from the external shock with an increase in capital flows, a decrease in exchange rates and a decrease in asset value. On the other hand, countries such as Thailand and Vietnam achieved a stable financial market and economic growth in the face 
of external shock. Tunay and Tunay (2019) analysed the effectiveness of monetary policy against to external shocks in Turkey on a simple New Keynesian model by using a SVAR model. In this study, financial stability represented by the credit deficit variable and the study covers the period between 1987 and 2018. Findings obtained as a result of SVAR model determined that the effects of financial shocks on macroeconomic variables are both strong and long-term. Apaydın and Şahin (2017) examined the effects of short-term capital flows on economic fluctuations in Turkey by using a long-run restricted SVAR model. The empirical findings obtained as a result of the study revealed that short-term capital flows caused significant fluctuations in the real sector of the economy through real exchange rates.

With respect to the experiences of sudden stop, there are plentiful examples in the empirical literature. Especially, after the 1994 Mexico and 1997 Asia crises, sudden stops in capital flows became an important topic among researchers. In this context, a brief review of studies that investigates sudden stop phenomena in the empirical literature are shown in the following table.

Table 1. A Brief Review of Literature

\begin{tabular}{|c|c|c|c|}
\hline Author & Sample & Method & Result \\
\hline $\begin{array}{l}\text { Calvo, Izquierdo } \\
\text { and Mejía } \\
(2004)\end{array}$ & $\begin{array}{l}\text { Selected Developed } \\
\text { and Developing } \\
\text { Countries }\end{array}$ & $\begin{array}{l}\text { Panel Probit } \\
\text { Regression }\end{array}$ & $\begin{array}{l}\text { It is asserted that sudden stop has } \\
\text { significant effect on economic growth. } \\
\text { Real exchange rate depreciations occur } \\
\text { with sudden stop }\end{array}$ \\
\hline Turgutlu (2015) & Turkey & GMM & $\begin{array}{l}\text { It is showed that sudden stop of capital } \\
\text { into Turkey has resulted in significant } \\
\text { decline in bank lending }\end{array}$ \\
\hline $\begin{array}{l}\text { Agosin, Díaz- } \\
\text { Maureira and } \\
\text { Karnani (2016) }\end{array}$ & $\begin{array}{l}\text { Selected Developed } \\
\text { and Developing } \\
\text { Countries }\end{array}$ & $\begin{array}{l}\text { Multinomial } \\
\text { Logit Model }\end{array}$ & $\begin{array}{l}\text { It is provided that there is high correlation } \\
\text { between booms in capital flow and future } \\
\text { sudden stop. }\end{array}$ \\
\hline $\begin{array}{l}\text { Scholtens, de } \\
\text { Haan, Zhao and } \\
\text { Yang (2014) }\end{array}$ & Selected 59 Countries & $\begin{array}{l}\text { Panel Logit } \\
\text { Model and } \\
\text { Event Study }\end{array}$ & $\begin{array}{l}\text { They provide that economies with } \\
\text { relatively low trade openness, a shallow } \\
\text { financial sector and current account } \\
\text { imbalances are most vulnerable to } \\
\text { sudden stops with currency crashes }\end{array}$ \\
\hline $\begin{array}{l}\text { Bachmann and } \\
\text { Leist (2013) }\end{array}$ & $\begin{array}{l}\text { Indonesia and } \\
\text { Mexico }\end{array}$ & $\begin{array}{l}\text { Markov } \\
\text { Switching } \\
\text { VAR }\end{array}$ & $\begin{array}{l}\text { It is stated that sudden stop has negative } \\
\text { effects on growth. }\end{array}$ \\
\hline Mahecha (2013) & $\begin{array}{l}\text { Selected Emerging } \\
\text { Markets Economies }\end{array}$ & $\begin{array}{l}\text { OLS and } \\
\text { Tobit }\end{array}$ & $\begin{array}{l}\text { Countries with lower foreign debt } \\
\text { experienced a less costly crisis. A } \\
\text { countercyclical fiscal policy and the sale of } \\
\text { international reserves against the } \\
\text { depreciation of the local currency also } \\
\text { helped to reduce the cost of sudden stops } \\
\text { on output. }\end{array}$ \\
\hline $\begin{array}{l}\text { Agosin and } \\
\text { Huaita (2012) }\end{array}$ & $\begin{array}{l}42 \text { Emerging Markets } \\
\text { Economies }\end{array}$ & Probit Model & $\begin{array}{l}\text { Sudden stop in capital flow has negative } \\
\text { effects on economics }\end{array}$ \\
\hline $\begin{array}{l}\text { Joyce and } \\
\text { Nabar (2009) }\end{array}$ & $\begin{array}{l}26 \text { Emerging Market } \\
\text { Economies }\end{array}$ & GMM & $\begin{array}{l}\text { Strong banking system in an economy is } \\
\text { an important factor against sudden stop. } \\
\text { If banking system is strong, sudden stop in } \\
\text { capital doesn't have effect on economy. }\end{array}$ \\
\hline $\begin{array}{l}\text { Neagu and } \\
\text { Mihai (2013) }\end{array}$ & Romania & Stress Test & $\begin{array}{l}\text { With some burden, economies can } \\
\text { withstand against shocks such as sudden } \\
\text { stop. }\end{array}$ \\
\hline Sula (2010) & $\begin{array}{l}\text { Selected } 36 \text { Emerging } \\
\text { Market Economies }\end{array}$ & $\begin{array}{l}\text { Panel } \\
\text { Regression } \\
\text { Model }\end{array}$ & $\begin{array}{l}\text { High current account deficit and } \\
\text { appreciated real exchange rate cause } \\
\text { sudden stops and this result creates } \\
\text { negative effects on the economy. }\end{array}$ \\
\hline
\end{tabular}


Table 1. A Brief Review of Literature (Continued)

\begin{tabular}{|c|c|c|c|}
\hline $\begin{array}{l}\text { Gallego and } \\
\text { Tessada (2010) }\end{array}$ & $\begin{array}{l}\text { Brazil, Chile, } \\
\text { Colombia, Mexico, } \\
\text { Argentina, Uruguay }\end{array}$ & $\begin{array}{l}\text { Panel } \\
\text { Regression } \\
\text { Model }\end{array}$ & $\begin{array}{l}\text { Sudden stops are associated with reduced } \\
\text { job creation and particularly increased job } \\
\text { destruction. }\end{array}$ \\
\hline $\begin{array}{l}\text { Agosin, Diaz } \\
\text { and Karnani } \\
\text { (2019) }\end{array}$ & $\begin{array}{l}22 \text { Developed and } 37 \\
\text { Emerging Market } \\
\text { Economies }\end{array}$ & $\begin{array}{l}\text { Pooled } \\
\text { Multinomial } \\
\text { Logit Model }\end{array}$ & $\begin{array}{l}\text { Correlation between capital inflows and } \\
\text { outflows is an important indicator for } \\
\text { possibility of experiencing sudden stop } \\
\text { problem in the future. This connection } \\
\text { may be affected by policy that } \\
\text { implementing in countries }\end{array}$ \\
\hline $\begin{array}{l}\text { Reyes-Heroles } \\
\text { and Tenorio } \\
(2019)\end{array}$ & $\begin{array}{l}23 \text { Emerging Market } \\
\text { Economies }\end{array}$ & $\begin{array}{l}\text { Markov } \\
\text { Switching } \\
\text { VAR }\end{array}$ & $\begin{array}{l}\text { There is a high correlation between } \\
\text { interest rates volatilities and possibility of } \\
\text { sudden stop occurrence }\end{array}$ \\
\hline $\begin{array}{l}\text { Wu, Hu and Pan } \\
\text { (2019) }\end{array}$ & $\begin{array}{l}30 \text { Emerging Market } \\
\text { Economies }\end{array}$ & $\begin{array}{l}\text { Panel } \\
\text { Regression } \\
\text { Model }\end{array}$ & $\begin{array}{l}\text { Economies with better infrastructure, } \\
\text { strong banking system and high growth } \\
\text { potential are less affected by the sudden } \\
\text { stop caused by external shocks }\end{array}$ \\
\hline $\begin{array}{l}\text { Jung, Kim and } \\
\text { Yang (2018) }\end{array}$ & $\begin{array}{l}\text { China, Hong } \\
\text { Kong, India, } \\
\text { Indonesia, Korea, } \\
\text { Malaysia, Thailand, } \\
\text { and the Philippines }\end{array}$ & $\begin{array}{l}\text { Block Exogen } \\
\text { Panel VAR } \\
\text { Model }\end{array}$ & $\begin{array}{l}\text { Emerging Market Economies without } \\
\text { capital controls are more vulnerable to } \\
\text { exogenous shocks and these economies } \\
\text { experiences long-term and disruptive } \\
\text { economic recession when compared with } \\
\text { economies that applies optimal capital } \\
\text { controls }\end{array}$ \\
\hline $\begin{array}{l}\text { Chen and Tsang } \\
\text { (2018) }\end{array}$ & Hong Kong & FAVAR & $\begin{array}{l}\text { External shocks triggers to capital outflow } \\
\text { but it has not significant effect on real } \\
\text { economy for Hong Kong because of } \\
\text { successful macro-prudential policies }\end{array}$ \\
\hline
\end{tabular}

Source: Prepared by authors.

\section{Methodology}

\subsection{Data}

In this study, it is investigated effects of external shocks, which is one of the causes of sudden stop problem on Turkish Economics Performance. Although there are internal and external factors causing sudden problem, we take the external factors as the reason based on the small open economy assumption in this study. These external factors are can be summarized as unexpected changes in international interest rates, contagion effect and volatility in financial markets (Milesi-Ferretti \& Razin, 1998; Calvo, 2003; Guidotti et al., 2004; Mendoza, 2010). From this viewpoint, we choose Fed effective funds rate as proxy variable for unexpected changes in international interest rate.

Our purpose of selecting this variable is that when unexpected increases occur at Fed effective funds rate, capital inflow start to slow down and this will cause sudden stop problem at a later stage.

For domestic economy, current account balances, current financial account, consumer price index, industrial production index proxy and domestic interest rate are defined as factors that determine economic performance. These variables are intensely utilized in the literature such as Agosin and Huaita (2012); Catão and Milnesi-Ferretti (2014); Christensen and Li (2014). The industrial production index, consumer price index and domestic interest rate are well-known variables in monetary business cycle literature (Kim \& Roubini, 2000). In addition, we use nominal GDP variables to transform current account balance and current financial account. 
Our dataset spans from 2003:01 to 2019:09 on monthly basis. They were obtained from Thompson Reuters Data Stream software. The nominal GDP that used in our study is interpolated and transformed from quarterly to monthly by utilizing cubic formulation.

Table 2. Data and Process

\begin{tabular}{|l|l|c|}
\hline Variables & Process & Abbreviation \\
\hline Current Financial Account / NGDP (-1) & Level & CFA \\
\hline Real Effective Exchange Rate & Log + First Difference & REER \\
\hline Nominal GDP & Interpolate + Seasonal Adjustment & NGDP \\
\hline Domestic Interest Rate & First Difference & INT \\
\hline Private Sector Credits & Log + First Difference & CRDT \\
\hline Current Account Balance / NGDP (-1) & Level & CAB \\
\hline Industrial Production Index & $\begin{array}{l}\text { Seasonal Adjustment + Log + First } \\
\text { Difference }\end{array}$ & IPI \\
\hline Consumer Price Index & $\begin{array}{l}\text { Seasonal Adjustment + Log + First } \\
\text { Difference }\end{array}$ & CPI \\
\hline Fed Effective Fund Rates & First Difference & FEDEF \\
\hline
\end{tabular}

In time series analyses, the series that analysed must be stable in order to obtain meaningful econometric relationships between them. Unit root tests are often used to test whether the series have a stable structure or not. Before proceedings our analysis, we applied Augmented Dickey and Fuller (ADF), Phillips and Perron (PP) and Kwiatkowski, Phillips, Schmidt and Shin (KPSS) unit root tests. According to test results, current financial account and current account balance are stationary at level, while consumer price index, industrial production index and real exchange rate and are not stationary at level.

Table 3. Unit Root Test Results

\begin{tabular}{|l|c|c|c|c|c|c|}
\hline & \multicolumn{2}{|c|}{ ADF } & \multicolumn{2}{c|}{ PP } & \multicolumn{2}{c|}{ KPSS } \\
\hline Data & Intercept & $\begin{array}{c}\text { Trend and } \\
\text { Intercept }\end{array}$ & Intercept & $\begin{array}{c}\text { Trend and } \\
\text { Intercept }\end{array}$ & Intercept & $\begin{array}{c}\text { Trend and } \\
\text { Intercept }\end{array}$ \\
\hline $\begin{array}{l}\text { CFA/NGDP (- } \\
1)\end{array}$ & $-11.12307^{* * *}$ & $-11.50571^{* * *}$ & $-11.2791^{* * *}$ & $-11.5057^{* * *}$ & $0.547978^{*}$ & $0.071963^{* * *}$ \\
\hline LCPI & 1.560335 & -0.340117 & 1.610401 & 0.590320 & 1.765513 & $0.205545^{*}$ \\
\hline LREER & -0.963568 & -2.703943 & -1.193960 & -2.730332 & 0.955305 & 0.386931 \\
\hline LIPI & -1.484479 & -2.159154 & -1.206874 & -2.459064 & 1.706789 & $0.075917^{* * *}$ \\
\hline INT & $-4.258548^{* * *}$ & $-3.816497^{* *}$ & $-3.877913^{* *}$ & -2.870909 & 0.786009 & 0.341238 \\
\hline LCRDT & $-4.915024^{* * *}$ & -1.945802 & $-5.036226^{* * *}$ & -1.608238 & 1.744813 & 0.340623 \\
\hline $\begin{array}{l}\text { CAB/NGDP (- } \\
1)\end{array}$ & $-3.430160^{* * *}$ & $-3.392002^{*}$ & $-5.533225^{* * *}$ & $-5.563587 * * *$ & $\begin{array}{c}0.221753^{*} \\
* *\end{array}$ & $0.198892^{*}$ \\
\hline FEDEF & -1.573032 & $-3.910239^{* *}$ & -1.341440 & -1.377778 & $0.508161 *$ & $0.190704^{*}$ \\
\hline
\end{tabular}

Source: Authors' computation

Note: ${ }^{* *},{ }^{* *}$ and ${ }^{*}$ show that test values are statistically significant at the $1 \%, 5 \%$ and $10 \%$ levels, respectively. The null hypothesis of the ADF and PP tests is that the series are nonstationary, while null hypothesis of KPSS test is that series are stationarity. 
Furthermore, considering that there may also be structural breaks in the data, we applied structural break unit root test in order to indicate biased results for standard unit root test. For this purpose, we utilized Lagrange Multiplier (LM) two structural breaks unit root test developed by Lee and Strazicich (2003). This test was also supported by Bai-Perron Multiple Breakpoint Test to show that there are structural breaks. BaiPerron test results are available in Table - A1 in the appendix section

Table 4. Lee and Strazicich Test Result

\begin{tabular}{|c|c|c|c|c|c|}
\hline \multicolumn{6}{|c|}{ Model A (Crash model) } \\
\hline Data & LM-Stat & $\lambda_{1}$ & $\lambda_{2}$ & $\begin{array}{l}\text { Breaking } \\
\text { Time }\left(\mathrm{TB}_{1}\right)\end{array}$ & $\begin{array}{l}\text { Breaking Time } \\
\left(\mathrm{TB}_{2}\right)\end{array}$ \\
\hline CFA/NGDP $(-1)$ & $-7.275^{* * *}$ & 0.325 & 0.635 & 2008:06 & 2013:08 \\
\hline LCPI & -1.732 & 0.502 & 0.836 & 2011:04 & 2016:11 \\
\hline LREER & -2.144 & 0.318 & 0.333 & 2008:03 & 2008:06 \\
\hline LIPI & $-3.861 * *$ & 0.413 & 0.522 & 2009:10 & 2011:08 \\
\hline INT & -1.156 & 0.512 & 0.662 & 2011:07 & 2014:01 \\
\hline LCRDT & -1.668 & 0.100 & 0.109 & 2004:08 & 2004:10 \\
\hline CAB/NGDP (-1) & $-4.22 * *$ & 0.350 & 0.515 & 2008:11 & 2011:08 \\
\hline FEDEF & $-3.739 *$ & 0.313 & 0.343 & 2008:03 & 2008:09 \\
\hline \multicolumn{6}{|c|}{ Model C (Trend shift model) } \\
\hline Data & LM-Stat & $\lambda_{1}$ & $\lambda_{2}$ & $\begin{array}{l}\text { Breaking } \\
\text { Time }\left(\mathrm{TB}_{1}\right)\end{array}$ & $\begin{array}{c}\text { Breaking Time } \\
\left(\mathrm{TB}_{2}\right)\end{array}$ \\
\hline CFA/NGDP (-1) & $-12.182 * * *$ & 0.180 & 0.390 & 2006:01 & 2009:07 \\
\hline LCPI & $-5.451^{*}$ & 0.368 & 0.876 & 2009:01 & $2017: 07$ \\
\hline LREER & $-6.556 * * *$ & 0.353 & 0.876 & 2008:10 & 2017:07 \\
\hline LIPI & -5.070 & 0.323 & 0.453 & 2008:04 & 2010:06 \\
\hline INT & -4.737 & 0.234 & 0.468 & 2006:11 & 2010:10 \\
\hline LCRDT & -4.375 & 0.279 & 0.692 & 2007:08 & $2014: 07$ \\
\hline CAB/NGDP (-1) & $-5.838 * *$ & 0.470 & 0.870 & 2010:11 & 2017:07 \\
\hline FEDEF & $-6.954 * * *$ & 0.294 & 0.507 & 2007:11 & 2011:06 \\
\hline
\end{tabular}

Source: Authors' computation

Note: The critical values are acquired from Lee and Strazicich (2003). Model A is for breaks in the intercept, while Model $\mathrm{C}$ is for breaks in both the intercept and the trend. $\mathrm{TB}_{1}$ and $\mathrm{TB}_{2}$ indicate the first and second break dates, while $\mathrm{TB}_{1 \mathrm{t}}$ and $\mathrm{TB}_{2 \mathrm{t}}$ indicate the first and second break dates for the trend and intercept. ${ }^{* * *}, * *$ and $*$ indicate statistical significance at the $1 \%, 5 \%$, and $10 \%$ levels, respectively.

As seen from table 3, current financial account and current account balance is stationary at level. However, consumer price index, industrial production index, credit to private sector real exchange rate and Fed effective funds rate is not stationary at level. Therefore, those variables are used as first difference form in the SVAR model. When investigating break dates, they generally appear to correspond to the 2008 global financial crisis and the following years.

\subsection{Model}

Structural VAR (SVAR) model allows to transform a VAR model in a reduced form into a system of structural equations by utilizing economic theory. In the classical VAR model, outcomes can change with order of variables. However, in structural VAR models introduced by Bernanke (1986) and Sims (1986) as alternative to classical VAR models, structural parameters and structural shocks are determined by identifying constraints that chosen according to economic theory on the variables in the model. When we consider the following equation; 
$Y t=A Y t-1+\ldots \ldots+A p Y t-p+\Psi D t+\mu t$

where $\mathrm{p}$ is represented as optimal lag for $\mathrm{VAR}, \mathrm{Y}$ is represented as $\mathrm{n} \times 1$ dimensional endogenous variable matrix, $\mu \mathrm{nx} 1$ is residuals matrix and $D t$ is deterministic compound which can be easily neglected because it is not influenced by a shock. Therefore, SVAR model can be showed off as following way;

$$
A Y t=A Y t-1+\ldots \ldots+A p Y t-p+B \epsilon t
$$

With respect to equation, $A$ matrix represent instantaneous relations and $B$ matrix represent the structural formation parameters of model. $\epsilon t$ is matrix of structural problems in $\mathrm{nx} 1$ dimension and $\operatorname{var}(\epsilon t)$ $=\Lambda$. $\Lambda$ is the diagonal matrix. Since some shocks cannot directly observed, certain identifications should be used.

\subsubsection{Block Exogeneity Assumption with SVAR}

Since we investigate whether external shocks can cause sudden stop or not in Turkey, structural VAR with block exogeneity introduced by Cusman and Zha (1997) is used in this study. Our aim of using this model is that block exogeneity approach provide suitable constraint under the assumption of small-open economy. In this approach, external variable has impact on domestic variables, whereas domestic variable cannot affect to external variable (Kim \& Roubini, 2000). Thanks to this model, the results are statistically more consistent and more suitable for theoretical background than standard SVAR model

In this context, there are the studies that utilizing block exogeneity assumption to investigate relationship between open small economy and world in literature as well.

For example; the structural VAR model with the block exogeneity is used by Mackowiak (2007) to analyse the impact of external shocks on developing countries. In addition, this method is used by Calvallo and Franken (2008) to investigate the Chilean economy.

Considering following structural form equation;

$$
\mathrm{A}(\mathrm{L}) \mathrm{y}(\mathrm{t})=\varepsilon(t)
$$

where $y(t)$ is a $m \times 1$ vector of observations at time $t, A(L)$ is a non-singular $m \times m$ matrix in lag operator $L$, and $\varepsilon(t)$ is $\mathrm{m} \times 1$ structural disorders. When the matrices are rearranged in accordance with the block externality assumption.

$$
\begin{aligned}
& y(t)=\left[\begin{array}{l}
y d(t) \\
y e(t)
\end{array}\right] \\
& A(L)=\left[\begin{array}{ll}
A 11(L) & A 12(L) \\
A 21(L) & A 22(L)
\end{array}\right]
\end{aligned}
$$

and

$$
\varepsilon(t)=\left[\begin{array}{l}
\varepsilon d(t) \\
\varepsilon e(t)
\end{array}\right]
$$

where $y d(t)$ is $m_{1} \times 1$ vector of internal variables, and ye(t) is $m_{2} \times 1$ vector of exogenous variables at time $t$. The dimension of $A 11(L)$ is $\mathrm{m}_{1} \times \mathrm{m}_{1}, A 12(L)$ is $\mathrm{m}_{1} \times \mathrm{m}_{2}, A 22(L)$ is $\mathrm{m}_{2} \times \mathrm{m}_{2}, \varepsilon d(t)$ is $\mathrm{m}_{1} \times 1$, and $\varepsilon e(t)$ is $\mathrm{m}_{2} \times 1$. Consequently, structural distributions satisfy the following conditions;

$$
E\left[\varepsilon(t) \varepsilon(t)^{\prime} \mid y(t-s), s>0\right]=I, E[\varepsilon(t) \mid y(t-s), s>0]=0
$$


The reduced form is described in following way;

$(L)(t)=(t)$, then, structural disturbances are associated with residuals of reduced form equation by $(t)=A 0(t)$. From this point of view, constraint matrix that we use in the study is as follows;

\begin{tabular}{|c|c|c|c|c|c|c|c|c|c|c|c|}
\hline$\varepsilon c f a$ & & 1 & $a_{12}$ & $a_{13}$ & 0 & 0 & 0 & $a_{16}$ & $a_{17}$ & $a_{18}$ & ucfa \\
\hline creer & & $a_{21}$ & 1 & $a_{23}$ & 0 & 0 & 0 & $a_{26}$ & $a_{27}$ & $a_{28}$ & ureer \\
\hline cint & & 0 & 0 & 1 & 0 & 0 & 0 & 0 & $a_{37}$ & $a_{38}$ & uint \\
\hline$\varepsilon c r d t$ & $=$ & $a_{41}$ & 0 & $a_{43}$ & 1 & 0 & 0 & 0 & 0 & $a_{48}$ & ucrdt \\
\hline eipi & - & $a_{51}$ & $a_{52}$ & $a_{53}$ & $a_{54}$ & 1 & 0 & 0 & 0 & $a_{58}$ & uin \\
\hline$\varepsilon c a b$ & & 0 & $a_{62}$ & $a_{63}$ & $a_{64}$ & 0 & 1 & 0 & 0 & $a_{68}$ & ucab \\
\hline$\varepsilon c p i$ & & 0 & $a_{72}$ & 0 & $a_{74}$ & 0 & 0 & 0 & 1 & $a_{78}$ & ucpi \\
\hline Lffedef & & 0 & 0 & 0 & 0 & 0 & 0 & 0 & 0 & 1 & -ufedef \\
\hline
\end{tabular}

This identification structure is more accurate and realistic compared to Cholesky decomposition therefore it provides meaningful results. Above matrix form shows restriction matrix. These restrictions are determined by the economic priors. By means of these identifications, variables simultaneously react to other domestic and external variables. For example, capital inflow can respond to both endogenous and exogenous variables respectively interest rate and Federal Reserve funds rate. However, in the Cholesky decomposition is not possible to obtain inference in such way (Tunc \& Kilic, 2014).

According to this identification scheme, while Fed effective funds rate variable affecting domestic variables, it cannot be affected by domestic variables. The domestic variables are in simultaneous interaction with each other and with external variables Moreover, the block exogeneity assumption allows to include exogenous variables in the model.

In this way, as external variable affects to domestic variables, it cannot be affected by domestic variables. The block exogeneity restriction, $A 21(L)=0$ means that endogenous variables do not affect the structural forms of external variables for simultaneous or lagged forms. It can be said that this assumption is appropriate for small-open economy framework and play important role in identification structure (Tunc \& Kilinc, 2016).

\subsubsection{A Bayesian Approach in Estimation}

In this study, we estimate our model by using Bayesian Gibbs sampling methodology as it is in Zha (1999) and Waggoner and Zha (2003). "The advantage of this approach is that it provides precise statistical results for models with a high degree of simultaneity among the simultaneous variables, besides for models with restricted variance-covariance matrices of the residuals and for models with restrictions on lagged coefficients because "when the degree of simultaneity in a structural model is high, the shape of the posterior density for the model parameters tends to be so non-Gaussian that importance sampling is prohibitively inefficient (Waggoner \& Zha, 2003)".

In our model, since there is high simultaneity among variables that uses in model, Gibbs sampling is chosen in order to obtain meaningful inference from model. When we estimating this structural model, The RATS 10.0 econometric software is used and two-lag chosen for system owing to small sample (Sato, Zhang \& McAleer, 2011).

\section{Results}

Impulse-response analysis can help to interpret the effects of one-standard deviation shock is given to Fed funds rate on domestic variables and it shows their interactions. The figure 1.1 reports the onestandard deviation positive shock from Fed effective funds rate (FED interest rate). The increases in Fed effective funds rate trigger to decreases capital flows into Turkey at first period and this effect continues until the third period. The results reveal that external shocks negatively affect capital inflows. This situation is supported by many studies that investigating the sudden stop problem for EMEs in the literature such as Mendoza (2010), Calvo et al. (2006), Bacchetta and van Wincoop (2000), Kaminsky et al. (2004), and Reinhart 
(2008). Related studies in the literature acknowledge that external shocks are one of the main factors affecting the sudden stop problem. In addition, the real effective exchange rate begins to depreciate and continues until the second period. The depreciation in the real exchange rate is considered as one of the main dynamics of the sudden stop problem (Calvo, 1998; Calvo et al., 2004; Guidotti et al., 2004; Cavallo \& Frankel, 2008; Rothenberg \& Warnock, 2011; Seoane \& Yurdagul, 2019). Our results support this phenomenon.

In addition, the domestic interest rate increases until the third period. The reason for this is that most of the emerging market economies prefer policy interest as a stabilization policy tool to prevent exchange rate depreciation and capital outflows (Devereux \& Yetman, 2014). When evaluated from this perspective, the findings of the study coincide with the previous studies. The credits to private sectors decrease up to fifth period after first period. In this case, increases in borrowing costs arising from volatility in domestic interest rate can be considered as the reason for the decreases in credits to private sector. The industrial production index decreases between first period and second period against one-standard deviation positive shocks is given to fed effective funds rate. Since, the increases in interest rate contract domestic demand and makes credits more costly, real sector is negatively affected and output decreases. This case is one of the characteristic features caused by sudden stop in EMEs (Calvo et al., 2008). The current account balance increases up to eighth period after second period. It is contraction in the current account deficit. This situation is expressed in the literature as a current account reversal which is one of the results of sudden stop (Edwards, 2004). The depreciation in real exchange rate causes to increase demand for domestic goods and it reduces domestic demand for foreign goods that's why current account deficit shrinks. Moreover, the consumer price index increases between first period and second period. The depreciations in real exchange rate puts upward pressure on inflation due to pass-through effect and inflation increases.

While the interest rate increases, the increases in exchange rate are called the as exchange rate puzzle. However, this is not the case in here. Since Turkish economy is small-open economy, increases in interest rate cannot prevent to deprecations that arise from external factor in real effective exchange rate because other factors play an active role in this situation. Furthermore, this situation also proves that the classical macroeconomic policies are not realistic in terms of Turkey sampling.

Figure 1. Impulse - Response of FED Effective Funds Rate
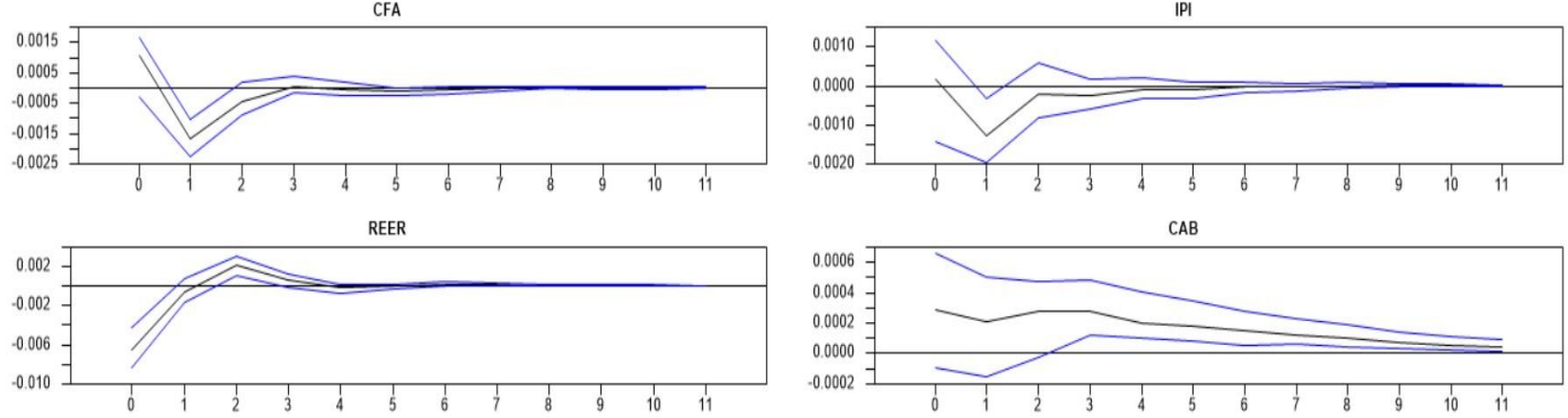

INT
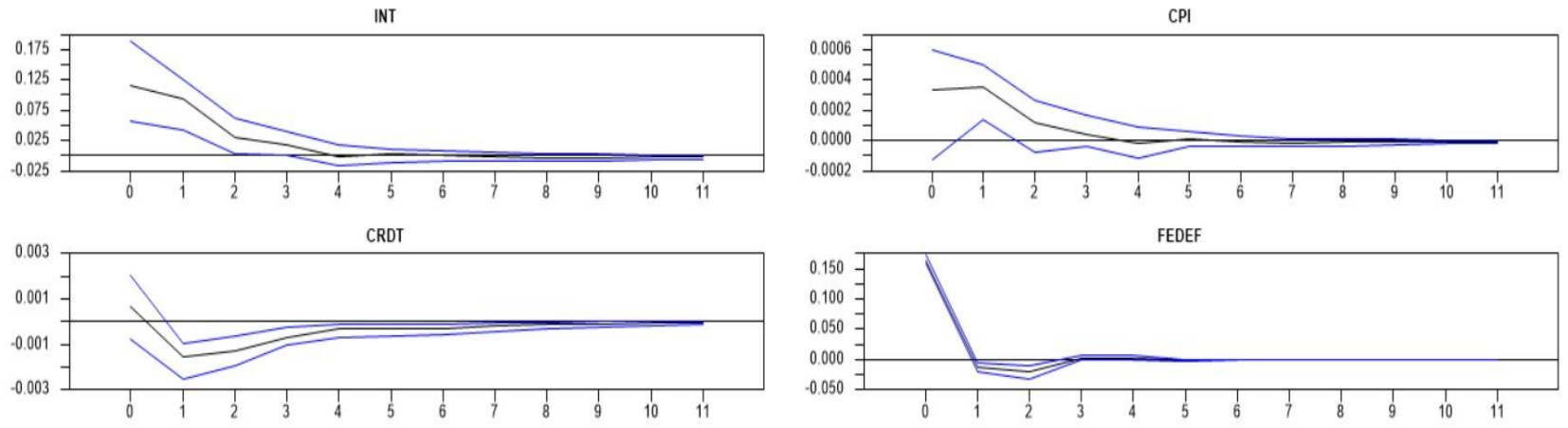

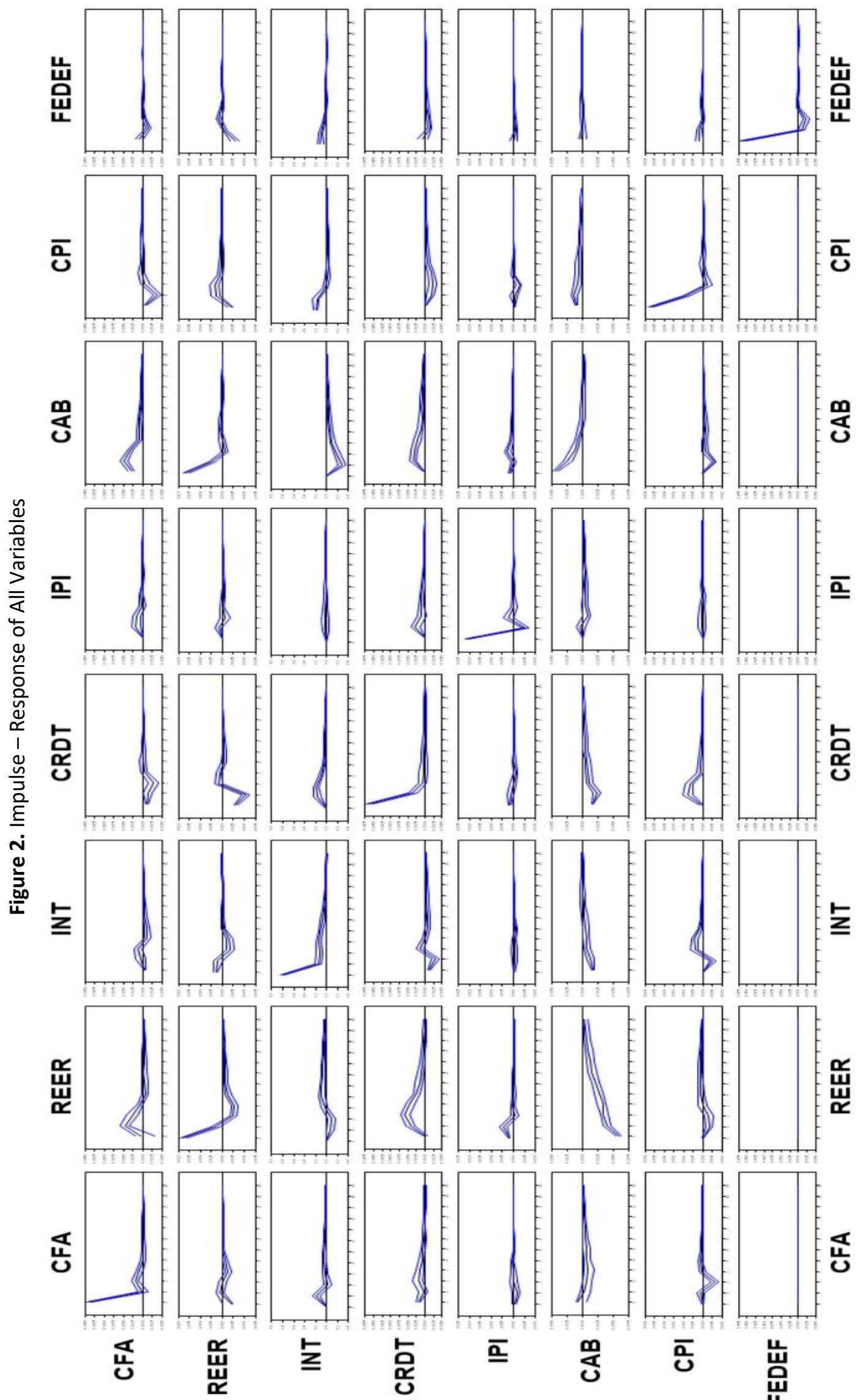


\section{Conclusion}

This study aims to investigate the effects of sudden stop problem on Turkish economy. In this context, in order to investigate sudden stop problem, the study is driven by small-open economy assumption. As stated in the study, sudden stop generally arises from external factors such as changes in world interest rate, imbalances in financial market, contagion effect or similar external factors. Therefore, Fed effective funds rate is preferred as triggering factor for sudden stop event. To apply this, empirical approach of the SVAR model with block exogeneity is used. Our aim in using this methodology, the SVAR model with block exogeneity allows to apply small-open economy assumption.

In the model, several variables can be used as exogenous and endogenous. Moreover, in this model, while exogenous variable affects the endogenous variable, endogenous variable but not. Contrary to VAR model, this model theoretically improves the inferences of analysis.

On the other hand, data used in study are monthly and it span from 2003:01 to 2019:09. The data set of this study consist of current account balance that represent capital flows, real effective exchange rate, industrial production index, consumer price index, current account balance, domestic interest rate, credits to private sector and Fed effective funds rate. Whereas Fed effective funds rate is exogenous variable, others are endogenous variable. The result of study meets our expectations for Turkey sample. The positive shock that come from Fed effective funds rate launch sudden stop events. The sudden stop in capital inflows cause depreciations in real effective exchange rate and current account deficit shrinks. This situation is called as current account reversal in the literature. In this context, depreciation in the real effective exchange rate causes to decrease in industrial production index and it supports previous studies in the literature as well. Also, the domestic interest rate is increased to prevent capital outflows and depreciation in real effective exchange rate. Furthermore, the increases in interest rate may have occurred in keeping with price stability if taken into account during the increases in inflation.

On the other hand, it can be said that the problem of the currency mismatch, which is an important in terms of emerging market economies, arising from the real effective exchange rate depreciation exists in this economy. The increased real exchange rate will adversely affect the external debt burden. As a result, it can be said that when Fed funds rate hikes, it triggers to sudden stop event for Turkey in our sample. Firstly, capital flows decrease and then real effective exchange rate depreciates in order to mitigate the effects of them domestic interest rate is increased. This increases in domestic interest rate shows conventional monetary policy tool is used. However, it is understood that the only conventional monetary policy tool is not effective at alleviating this effect.

\section{Disclosure Statements}

1. The authors of this article are admitted that they complied with the principles of research and publication ethics.

2. No potential conflict of interest was reported by the authors.

3. This article was screened for potential plagiarism using a plagiarism screening program.

\section{End Notes}

1. This paper was extracted from the Master's Thesis titled "The Effects of Sudden Stop in Emerging Market Economies: The Case Study of Turkey" by Mehmet ÖBEKCAN (2016), conducted and defended under the supervision of Assoc. Prof. Dr. Bilge Kağan ÖZDEMIR at Anadolu University, Institute of Social Sciences. The thesis was reviewed in this paper and the period covered by the data used in empirical analysis was extended to cover the period of 2003:12019:9. 


\section{References}

Agosin R., Díaz-Maureira., J., \& Karnani, M. (2016). Sudden stops of capital flows: The role of outflows as a mechanism to offset sudden stops of inflows. Serie Documentos de Trabajo, 436, 1 - 27.

Agosin, M. R., \& Huaita, F. (2012). Overreaction in capital flows to emerging markets: Booms and sudden stops. Journal of International Money and Finance, 3, 1140-1155.

Apaydın, Ş., \& Şahin, H. (2017). Türkiye'de kısa vadeli sermaye akımlarının iktisadi dalgalanmalar üzerindeki etkileri: Bir uzun dönem kısıtlı SVAR modeli. Politik Ekonomik Kuram, 1(1), 22-72.

Bacchetta, P., \& van Wincoop, E. (2000). Does Exchange-Rate Stability Increase Trade and Welfare? The American Economic Review, 90(5), 1093.

Bachmann, A., \& Leist, S. (2013). Sudden stop regimes and output: A markov switching analysis. Universitaet Bern, Discussion Papers, 13-07.

Bernanke, B. S. (1986). Alternative explanations of the money-income correlation. Carnegie-Rochester Conference Series on Public Policy, 25(1), 49-99.

Caballero, R. J., \& Krishnamurthy, A. (2001). Smoothing sudden stops. Journal of Economic Theory, 119(1) $104-127$.

Calvo, G. (2003). Explaining sudden stop, growth collapse, and BOP crisis: the case of distortionary output taxes. IMF Economic Review, 1, 1-20.

Calvo, G. A. (1998). Capital flows and capital-market crises: The simple economics of sudden stops. Journal of Applied Economics, 1(1), 35-53.

Calvo, G. A. (1998). Capital flows and capital-market crises: The simple economics of sudden stops. Journal of Applied Economics, 1(1), 35.

Calvo, G. A., Izquierdo, A., \& Meija, L. F. (2004). On the empirics of sudden stops: The relevance of balance-sheet effects. NBER Working Papers.

Calvo, G. A., Izquierdo, A., \& Mejía, L. F. (2008). Systemic sudden stops: The relevance of balance-sheet effects and financial integration. Inter-American Development Bank Repository.

Calvo, G. A., Izquierdo, A., \& Talvi, E. (2006). Sudden stops and phoenix miracles in emerging markets. American Economic Review, 96(2), 405-410.

Calvo, G., \& Reinhart, C. (2001). Fixing for your life. NBER Working Paper, No. 8006.

Catão, L. A., \& Milesi-Ferretti, G. M. (2014). External liabilities and crises. Journal of International Economics, 94, 18-32.

Cavallo, E. A., \& Frankel, J. A. (2008). Does openness to trade make countries more vulnerable to sudden stops, or less? Using gravity to establish causality. Journal of International Money and Finance, 27(8), 1430-1452.

Christensen, I., \& Li, F. (2014). Predicting financial stress events: A signal extraction approach. Journal of Financial Stability, 14. 54-65.

Cushman, D. O., \& Zha, T. A. (1997). Identifying monetary policy in a small open economy under flexible exchange rates. Journal of Monetary Economics, 39, 33-48.

Devereux, M. B., \& Yetman, J. (2014). Globalisation, pass-through and the optimal policy response to exchange rates. Journal of International Money and Finance, 49(Part A), 104-128.

Dickey, D., \& Fuller, W. (1981). Likelihood ratio statistics for autoregressive time series with a unit root. Econometrica, 49(4), 1057-1072.

Dornbusch, R., Goldfajn, I., Valdés, R. O., Edwards, S., \& Bruno, M. (1995). Currency crises and collapses. Brookings Papers on Economic Activity, 2, 219-265.

Edwards, S. (2004). Financial openness, sudden stops, and current-account reversals. The American Economic Review, 94(2), 59-63.

Frankel, J., \& Rose, A. (2002). An estimate of the effect of common currencies on trade and income. The Quarterly Journal of Economics, 117(2), 437-466.

Gallego, F. A., \& Tessada, J. A. (2012). Sudden stops, financial frictions, and labour market flows: Evidence from Latin America. Journal of Development Economics, 97, 257-268.

Guidotti, P. E., Sturzenegger, F., \& Villar, A. (2004). On the consequences of sudden stops. Economia, 4(2), $171-214$.

Hutchison, M. M., \& Noy, I. (2006). Sudden stops and the Mexican wave: Currency crises, capital flow reversals and output loss in emerging markets. Journal of Development Economics, 79(1), 225-248.

Joyce, J. P., \& Nabar, M. (2009). Sudden stops, banking crises and investment collapses in emerging markets. Journal of Development Economics, 90, 314-322. 
Kaminsky, G. L., Reinhart, C. M., \& Végh, C. A. (2004). When it rains, it pours: Procyclical capital flows and macroeconomic policies. NBER/Macroeconomics Annual (MIT Press), 19, 11-53

Kilinc, M., \& Tunc, C. (2014). Identification of monetary policy shocks in Turkey: A structural VAR approach. Central Bank of Turkey, Working Papers, No.14/23

Kim, S., \& Roubini, N. (2000). Exchange rate anomalies in the industrial countries: A solution with a structural VAR approach. Journal of Monetary Economics, 45, 561-586.

Lee, J., \& Strazicich, M. C. (2003). Minimum lagrange multiplier unit root test with two structural breaks. Review of Economics and Statistics, (4), 1082.

Loayza, N. V., \& Raddatz, C. (2007). The structural determinants of external vulnerability. The World Bank Economic Review, 1, 359-387.

Maćkowiak, B. (2007). External shocks, U.S. monetary policy and macroeconomic fluctuations in emerging markets. Journal of Monetary Economics, 8, 2512-2520.

Mahecha, J. O. (2013). Sudden stops in emerging markets: How to minimize their impact on GDP? Documentos Cede, Universidad De Los Andes-Cede.

Mendoza, E. G. (2002). Why should emerging economies give up national currencies? A case for "institutions substitution". Inter-American Development Bank Repository, 1-35.

Mendoza, E. G. (2010). Sudden stops, financial crises, and leverage. American Economic Review, 100(5), $1941-1966$.

Milesi-Ferretti, G. M., \& Razin, A. (1998). Current account reversals and currency crises: Empirical regularities. NBER Working Papers, No. 6620.

Neagu, F., \& Mihai, I. (2013), Sudden stop of capital flows and the consequences for the banking sector and the real economy. European Central Bank Working Paper Series, No. 1591.

Reinhart, C. M., \& Reinhart, V. (2008). Capital flow bonanzas: An encompassing view of the past and present. NBER Working Papers.

Rothenberg, A. D., \& Warnock, F. E. (2011). Sudden flight and true sudden stops. Review of International Economics, 19(3), 509-524.

Sato, K., Zhang, Z., \& McAleer, M. (2011). Identifying shocks in regionally integrated East Asian economies with structural VAR and block exogeneity. Mathematics and Computers in Simulation, 81(7), 1353-1364.

Scholtens, B., de Haan, J., Zhao, Y., \& Yang, H. (2014). Sudden stops and currency crashes. Review of International Economics, 22(4), 660-685

Seoane, H. D., \& Yurdagul, E. (2019). Trend shocks and sudden stops. Journal of International Economics, 121.

Sims, C. A. (1986). Are forecasting models usable for policy analysis? Federal Reserve Bank of Minneapolis Quarterly Review, 10(1), 2-16.

Sims, C. A., \& T. Zha. (1999). Errors bands for impulse responses. Econometrica, 67, 1113-1155.

Stiglitz, J. (2002). Globalization and its discontents. New York: W. W. Norton.

Sturzenegger, F., Guidotti, P., \& Villar, A. (2003). Aftermaths of current account crisis: Export growth or import contraction? Business School Working Papers.

Sula, O. (2010). Surges and sudden stops of capital flows to emerging markets. Open Economies Review, 4, $589-605$.

Tunay, K., \& Tunay, N. (2019). Küçük dışa açık ekonomilerde makro finansal şoklar ve para politikalarının etkinliği: Türkiye örneği. Finans Ekonomi ve Sosyal Araştırmalar Dergisi, 4(4), 459-472.

Tunc, C., \& Kilinc, M. (2016). Exchange rate pass-through in a small open economy: A Structural VAR approach. MPRA Paper, No.72770.

Turgutlu, E. (2015). Impact of sudden stop and international reserves on bank lending: Evidence from Turkey. Hacettepe University Journal of Economics \& Administrative Sciences, 33(3), 131-148.

Waggoner, D. F., \& Zha, T. (2003). Likelihood preserving normalization in multiple equation models. Journal of Econometrics, 114, 329-347.

Winters, L. (2002). Trade liberalisation and poverty: What are the links? World Economy, 25(9), 1339-1367.

Wu, S., Hu, B., \& Pan, Q. (2019). The impact of the us interest rate hike on emerging market economies and the belt and road initiative. China and World Economy, 27(3), 126-142.

Zha, T. (1999). Block recursion and structural vector autoregressions. Journal of Econometrics, 90(2), 291-316. 


\section{Appendix}

Table 1. Bai - Perron Multiple Break Point Test

\begin{tabular}{|l|c|c|c|}
\hline Variable & Breaking Time (TB $)$ & Breaking Time (TB $)$ & LWZ Criterion \\
\hline CFA/NGDP (-1) & $2007 \mathrm{M} 11$ & $2015 \mathrm{M} 02$ & -9.004826 \\
\hline LCPI & $2008 \mathrm{M} 04$ & $2014 \mathrm{M} 06$ & $-3.576915^{*}$ \\
\hline LREER & $2013 \mathrm{M} 08$ & $2017 \mathrm{M} 01$ & $-4.936326^{*}$ \\
\hline LIPI & $2005 \mathrm{M} 09$ & $2012 \mathrm{M} 12$ & $-4.354257^{*}$ \\
\hline INT & $2005 \mathrm{M} 07$ & $2009 \mathrm{M} 03$ & $3.705576^{*}$ \\
\hline LCRDT & $2006 \mathrm{M05}$ & $2012 \mathrm{M} 04$ & $-1.579300^{*}$ \\
\hline CAB/NGDP (-1) & $2010 \mathrm{M} 11$ & $2014 \mathrm{M} 02$ & -9.004826 \\
\hline FEDEF & $2005 \mathrm{M} 07$ & $2008 \mathrm{M} 04$ & $-0.302527^{*}$ \\
\hline
\end{tabular}

Note: * show that test values are statistically significant at the $5 \%$ level. 
This Page Intentionally Left Blank 